\title{
Implementation of Google Calendar As an Android-based Agenda Application
}

\section{Marsofiyati}

Office Administration, Faculty of Economics, Universitas Negeri Jakarta, Indonesia

\section{Abstract}

This study aims to describe optimizing the implementation of Google Calendar as an Android-based agenda application. The research method in this study is a survey method. State of the art in previous studies have discussed the importance of technology in managing the agenda of technology activities mobile based on operations Android or Information and Communication Technologies (ICT). (1) Lack of the contention that the multi-faceted challenges of service leadership about communication support, for example, communicate between secretary and leader to manage schedule (2) Many studies only designed and built an application that how to manage the Agenda but had not examined the optimization of these applications. (3)

Corresponding Author:

Marsofiyati

marsofiyati@unj.ac.id

Received: 11 January 2019

Accepted: 14 February 2019

Published: 25 March 2019

Publishing services provided by Knowledge E

(c) Marsofiyati. This article is distributed under the terms of the Creative Commons

Attribution License, which permits unrestricted use and redistribution provided that the original author and source are credited.

Selection and Peer-review under the responsibility of the 3rd ICTVET 2018 Conference Committee. There are still many users, especially the leaders and secretaries who don't know how to operate Google Calendar. Use of electronic calendars is very useful for someone who has a very tight meeting schedule. The Google Calendar application is currently used by almost all users of webmail and android, but it is still rare to do research on the application. Design a reminder application on mobile-based academic activities to distribute and remind lecturers and students in carrying out academic activities on schedule. The design application to simplify schedule management, create and present the agenda to the Chancellor is made with its own scheduling application, does not optimize Google Calendar as an existing application. Google Calendar is an application that can help a good schedule and remind schedules regularly so that users do not worry about skipping a schedule that has been set up even if the work piles up.

Keywords: office administration application, secretary, scheduler, time schedule

\section{Introduction}

Technological developments are increasingly fast and we cannot impact the entire human lifeline, including office activities. Nowadays, information is so easy to move from one place to another, it can even be heard in seconds. The spread of this information has a lot of positive impacts and not a few also have a negative impact. Information in the office which was originally paper-based gradually began to be abandoned. In responding to this we cannot remain silent. At the moment we have to keep abreast 
of technology and use it wisely because if we do not follow these developments we will be left behind and only become spectators who cannot do anything. At present according to the report of the Indonesian Internet Service Providers Association [1] the Indonesian population reaches 262 million, and more than 50\% of them are internet users, with the majority of internet users as many as $72.41 \%$ coming from the urban and Java Islands the people use the internet the most, which is $57.70 \%$.

Various kinds of applications are displayed in helping office work, as well as application. The important role of the application is very helpful for office activities. In administrative activities the role of information and communication technology is currently used in the field of correspondence using electronic mail (e-mail), in the field of archives there is an electronic archive (e-filing) and online disposition (e-disposition), in the information field there are many letters online news, besides information and news that quickly spread through social media. The shift of mass media from newspapers to electronic newspapers and the spread of news through social media has a positive and negative impact. The positive impact of news spread that is so fast is that we can easily get news or information from anywhere and from anyone without requiring a long time, so there is no longer gap between one another. In addition, we do not need a large fee to receive or send news or information in all directions. However, in addition to having a large positive impact, the existence of information and communication technology also has a large negative impact, some of the negative impacts include the spread of false news (hoaxes). The tendency of hoax news to become viral does not escape the easy access reached by various parties. Besides that, it is difficult to sort or distinguish the correct news from false news.

\section{State of the Art}

Information delays and discrepancies are the main obstacles in office activities. Therefore it is necessary to have an application to connect with each other so that the information sent or received becomes more accurate and meaningful. The relationship between members of the team is one of the keys to the success of an organization, company, and agency. The application can connect information and communication between individuals and groups.

A leader is faced with a long schedule every day and work continues to accumulate resulting in difficulties in arranging and remembering the schedule or agenda of daily activities. Activity schedules are usually recorded and arranged neatly on the secretary's agenda and poured on the board as a leader reminder. The existence of technology 
makes the job easier and tidy and can be accessed anytime, anywhere by anyone. The task of recording and arranging agendas is easier and more organized.

Previous studies have discussed the importance of technology in managing the agenda of technology activities mobile based on operations Android or Information and Communication Technologies (ICT). Based on this, research is currently needed on information technology-based work agendas that can be connected to various devices, ICT whether computers or android or mobile phones that can be accessed at any time. However, these studies only design and build an application that will be used in the management of the Agenda but has not examined the optimization of these applications. Therefore, in this study, we will examine more deeply the optimization of existing applications, namely Google calendar, an application that is connected to electronic mail (e-mail) users and most widely used as the main requirement to operate android or mobile and other ICT devices. Lack of the contention that the multifaceted challenges of service leadership about communication support, for example, communicate between secretary and leader to manage schedule [2].

The use of Electronic Calendar can help in entering the meeting schedule, changing it, reviewing the schedule using an electronic calendar is very useful for someone who has a very tight meeting schedule [3]. The application is Google Calendar currently used by almost all users of webmail and android, but it is still rare to do research on the application. The preliminary study that has been carried out in the application of the agenda of activities is to build an application for managing activities and distributing these plans to many users on the Android operating system connected to manually entered data, Google Calendar, Google Task, and Google Contact. in the design of the leadership agenda application using technology mobile. Then the design of a reminder application on-based academic activities mobile to distribute and remind lecturers and students in carrying out academic activities on schedule. The design application to simplify the management of the agenda of the agenda, create an agenda and present an agenda to the Chancellor of Sam Ratulangi University, created with its own scheduling application, does not optimize the Google Calendar application as an available [4-6].

Currently, the application that is available and can be used free of charge integrated with email is numerous and has not been used optimally by internet users in general and email users in particular. Therefore, in this study, we want to explore thoroughly about one of the applications integrated with the email, especially Gmail, namely Google Calendar.

Reviewing Google Calendar as one application in Gmail, be our choice on the grounds that most of that is 1 billion email users are actively using Gmail [7] and 
continues to grow each year. The increase of Gmail users because Gmail web is unpaid (free) mail and unlimited text storage capacity, and for other than $10 \mathrm{~GB}$ text, and each year will continue to increase its capacity, besides Gmail also continues to improve its features and services.

As one of the applications in Gmail, Google Calendar is one of the applications that are needed, both by individuals and by organizations, companies or agencies, because this application is very helpful in managing one's schedule. Schedule settings are needed so that activities with one another do not overlap and collide or pass. Google Calendar can help schedule activities, coordinate and share timetable information to all desired people and get information automatically when ordering flight tickets, hotel or restaurant reservations via email received. In addition, Google Calendar also serves as a reminder of activities on the calendar that is created.

However, there are still many users, especially leaders and secretaries who do not know how to operate Google Calendar, which is one of the schedule setting applications and has a function as a reminder both for users personally and for some users by inviting to events and sharing schedule information to other users. This application is perfect for leaders who have many work agendas, and sometimes the work agenda overlaps with each other.

Aside from being a schedule manager Google Calendar also serves as a reminder, which can be used by anyone, anytime and anywhere. This is one of the main functions in setting schedules. Busyness often results in someone forgetting the schedule of activities on that day. This reminder application is very important in setting the schedule, with reminders that can be accessed via their respective mobile phones, making it easier for someone to quickly know what activities to do and what they have done. Alarm settings or reminder sounds can also be adjusted based on user's preferences or preferences. Because of the importance of this Google calendar for everyone. So it needs to be examined to what extent a person as a user can apply this Google Calendar in daily activities. This is in addition to being effective and efficient, of course pampering someone like having a personal assistant.

\section{Research Methodology}

The research method used in this study is a survey method using descriptive data. The survey method is a method used to obtain data from certain natural places, but the researchers treated them in data collection, for example, by circulating questionnaires, tests, structured interviews [8]. This method is intended to search for information or 
data regarding Google Calendar in helping with the preparation of work schedules or schedules and schedule reminders.

This study aims to describe the knowledge and understanding and optimize the implementation of Google Calendar as an Android-based agenda application that facilitates the setting of schedules or work agendas.

\section{Results and Discussion}

Based on the results of questionnaire responses of respondents who have done internships and work as administrators in various agencies and companies. In terms of preparing the schedule, as many as $53.8 \%$ said they agreed there were special officers or administrators who helped with the preparation of the schedule, this was stated if there was someone who took care of scheduling the activity schedule could be arranged properly. But this is difficult because agencies or companies always apply the principle of efficiency both in terms of the number of employees or employees and the tools or facilities used.

In overcoming the above problems, as many as $61.5 \%$ of respondents said that an application was needed that could help their schedule so that there were no missed schedules. Present without an application it turns out that sometimes a missed schedule can be seen from $53.8 \%$ of respondents saying so. This is certainly an important note for us that the difficulty in remembering the schedule is very high because the activities are very large and crowded, the arrangements are less organized, and the schedule settings cannot be managed alone. This is reinforced by the responses of respondents who stated that they sometimes forgot to remember the accumulated work schedule of $53.8 \%$, often forgot as much as $23.1 \%$, and never forgotten as much as $15.4 \%$. Based on the data above shows that more than $50 \%$ of a person will forget the schedule when dealing with accumulated work.

Another mistake that is often made in determining the schedule of activities is due to the inaccuracy of the administrator or secretary in checking the schedule. To avoid mistakes in overlapping or canceling an event there needs to be an action taken by an administrator or secretary in preparing the schedule, one of which is to carefully and carefully record each schedule and the incoming application. In addition, there needs to be an application that can help arrange the schedule quickly and accurately. This was evidenced by the responses from respondents who stated that the application schedule reminded of important schedules, with a variety of responses as many as $53.8 \%$ stated frequently, $30.8 \%$ stated always, and $15.4 \%$ stated sometimes. 
In this digital era, the need for various work applications is very high in order to help with office work. One of them is Google calendar application as one of the settings and schedule reminders, $84.6 \%$ of respondents said they knew Google calendar application and as many as $15.4 \%$ said they did not know the application. But from $84.6 \%$ who know Google calendar application not all use the application. It is proven that the number of users of Google Calendar applications is less than those who know the application is only $61.5 \%$ of respondents who use the remaining applications as much as $38.5 \%$ do not use the application.

The use of the Google Calendar application that has not been maximally turned out to be caused by the difficulty of the user in using the application, proved $30.8 \%$ stated difficulties in using the Google Calendar application.

Users know the Google calendar application as one of the schedule and reminder applications and state that the Google calendar has clear instructions in its use. In addition, the Google Calendar application can be run in various types of Android-based smartphones.

Users also agree that Google Calendar helps to schedule. This is supported by the statement $53.8 \%$ of users agreed to state that Google Calendar helped to schedule well. 23.1\% strongly agreed and $23.1 \%$ expressed doubt. In addition, Google Calendar as one of the scheduling applications can help schedule scheduling scales and of course can remind the schedule regularly so that users do not worry about skipping schedules that have been set since using Google Calendar.

\section{Conclusion}

This study result is that Google Calendar is an application that can help schedule the schedule well and can help schedule scheduling scales and can remind the schedule regularly so that the user is not worried about skipping the schedule that has been set even if the work piles up.

\section{References}

[1] Bohang, Fatimah Kartini. (2018). https://tekno.kompas.com/read/2018/02/22/ 16453177/berapa-jumlah-pengguna-internet-indonesia. February 22.

[2] Richard Teare Jim O'Hern, (2000), Challenges for service leaders: setting the agenda for the virtual learning organization. International Journal of Contemporary Hospitality Management, Vol. 12, Issue 2, pp. 97 - 106. 
[3] Marsofiyati, Henry Eryanto. (2015). Manajemen Perkantoran. Jakarta: LPP Pers Universitas Negeri Jakarta.

[4] Kadek, Putra Anggrian Mehendra. (2013). Pengembangan Aplikasi Daftar Perencanaan Kegiatan Berbagi Pakai pada Sistem Operasi Android. Jurnal Teknik Pomtts, Volume 7, Issue 2.

[5] Findra Kartika Sari Dewi. (2016). Rancang Bangun Aplikasi Pengingat Akademik Berbasis Mobile. Jurnal Buana Informatika, Vol. 7, Issue 4, pp. 303-312.

[6] Mandolan, Athur, Yaulie Deo Y. Rindengan, Steven R. Sentiniwo. (2017). Rancang Bangun Aplikasi Agenda Kegiatan Pimpinan (Studi Kasus: Rektorat Unstrat). EJournal Teknik Informatika, Vol. 11.

[7] Tempo.co. (2016). https://tekno.tempo.co/read/742614/Gmail-capai-1-miliarpengguna-aktif

[8] Sugiyono. Metode Penelitian Manajemen. Bandung: Alphabeta (2013). 